\title{
MICROBIOLOGIC PROFILE OF FLEXIBLE ENDOSCOPE DISINFECTION IN TWO BRAZILIAN HOSPITALS
}

\author{
Alexandre P. MACHADO ${ }^{1}$, Ana Teresa Mancini PIMENTA², Paulo P. CONTIJO², \\ Stephan GEOCZE ${ }^{3}$ and Olga FISCHMAN ${ }^{1}$
}

ABSTRACT - Background - Endoscopes are routinely used in hospitals and clinics of the world and they can be potential sources of cross-infection when the decontamination process is unsuitable. Aim - The routines of flexible endoscope (bronchoscopes, esophagogastroduodenoscopes and colonoscopes) disinfection procedures used in two Brazilian university hospitals were evaluated during a 3-year period. Methods - Aleatory samples from internal channels of endoscopes were collected after patient examination and after cleaning/disinfection procedures. Results - A contamination $>3 \log 10$ was achieved in samples recovered from endoscopes after patient examination. These samples yielded gram-negative bacilli $(n=142: 56 \%)$, gram-positive cocci $(n=43: 17 \%)$, yeast cells $(n=43: 17 \%)$, and gram-positive bacilli $(n=26: 10 \%)$. Approximately, 72 out of 149 samples $(48.32 \%)$ collected after undergoing the cleaning and disinfection procedures disclosed gram-negative bacilli $(n=55: 61 \%)$, gram-positive cocci $(n=21: 23 \%)$, gram-positive bacilli $(n=8: 9 \%)$ and yeast cells $(\mathrm{n}=6: 7 \%)$. Esophagogastroduodenoscopes and colonoscopes were the most frequently contaminated devices. Pseudomonas aeruginosa, Klebsiella pneumoniae, Escherichia coli, Enterobacter spp, Serratia marcescens, Proteus mirabilis, Citrobacter freundii, Staphylococcus aureus, Staphylococcus coagulase negative, Micrococcus luteus, Candida albicans, C. tropicalis, C. glabrata, C. guilliermondii, Bacillus spp and Corynebacterium spp were predominantly identified. Conclusion - Inappropriate cleaning and low times of disinfection were respectively the major factors associated with the presence of microorganisms in colonoscopes and esophagogastroduodenoscopes. By analyzing the identified germs, hospital disinfection was considered of either intermediate or poor level. After this investigation, both university centers improved their previous protocols for disinfection and conditions for reprocessing endoscopes.

HEADINGS - Equipment contamination. Disinfection. Endoscopes.

\section{INTRODUCTION}

The importance of reliable sterilization or high-level disinfection of reusable items in patient care that come into contact with open wounds, sterile body cavities, the blood-stream, or mucous membrane surfaces has greatly increased awareness due to infectious diseases, as AIDS, viral hepatitis and tuberculosis, more prions speculations $^{(5,7,16,26)}$. Endoscopes are routinely used in hospitals and clinics and they are potential sources of cross-infection when cleaning and disinfection are not effective ${ }^{(1,19,24)}$. Organisms isolated from these devices have been associated with pseudoepidemic infections and outbreaks ${ }^{(2,17,21)}$. In São Paulo (Brazil), the evaluation through questionnaires sent to public, private, and philanthropic hospitals showed that cleaning and disinfection procedures of endoscopes were inadequately performed in 38 of 39 analyzed institutions ${ }^{(10)}$. Therefore, the reason for the present study within two university hospitals was the lack of microbiologic data on cleaning and disinfection of endoscopes in Brazil.

\footnotetext{
' Department of Microbiology, Immunology and Parasitology, Federal University of São Paulo; ${ }^{2}$ Department of Biomedical Sciences, Federal University of Uberlândia, Uberlândia, MG; ${ }^{3}$ Endoscopy Service, "Hospital São Paulo", São Paulo, SP, Brazil

Poster presented at the 11th UEGW and published as an abstract in (Gut. 2003:52Suppl VI:A100).

Address for correspondence: Dr. Olga Fischman - Universidade Federal de Sao Paulo - Rua Botucatu, 862 - $8^{\circ}$ andar - 04023-062 - São Paulo, SP, Brazil. E-mail: alepaulo@ecb. epm.br; olga@ecb.epm.br
} 


\section{MATERIAL AND METHODS}

From 2000 to 2003, 298 samples collected from biopsy channel of bronchoscopes $(n=40)$, esophagogastroduodenoscopes (EGDs) $(n=138)$ and colonoscopes $(n=120)$ after patients examination and after usual decontamination procedures in two hospitals were analyzed. The cleaning of endoscopes was carried out with an enzymatic detergent solution, endozyme (LIFEZIME, Lab. Lifemed Medical Products Ltda). Manual disinfection was performed by soaking the device into $2 \%$ glutaraldehyde. The biopsy channel of bronchoscopes and EGDs was flushed thoroughly with $10 \mathrm{~mL}$ of sterilized phosphate buffered saline (PBS) by a disposable sterile syringe following clinical procedures and after the decontamination procedures. By using the same process, $20 \mathrm{~mL}$ of sterilized PBS were used in the colonoscope channel. Solutions were recovered in sterile tubes and immediately transported to the laboratory and processed. Homogenized $0.1 \mathrm{~mL}$ of each sample, and dilutions $1 / 10$ and $1 / 100$ in sterilized PBS, were inoculated onto three plates of $150 \times 15 \mathrm{~mm}$ respectively with tryptic soy agar (TSA), Sabouraud dextrose agar (SDA) with chloramphenicol, and MacConkey agar (Difco Laboratories). Residual glutaraldehyde was neutralized with sodium thiosulphate $0.6 \%$. TSA and MacConkey plates were incubated at $37^{\circ} \mathrm{C}$ and observed after 24,48 and 72 hours. SDA plates were incubated at $30^{\circ} \mathrm{C}$ and examined for 4 weeks. Random environmental specimens of rinse water were collected and cultured in the same media above mentioned. Different colony-types on each sample plate were selected for Gram stain characterization. The growth of each organism was quantified. Bacteria and fungi were identified according to classical techniques. Catalase production, growth in $\mathrm{NaCl}$, esculin hydrolysis, Dnase and coagulase tests were carried out for the identification of gram-positive cocci (Staphylococcus, Streptococcus and Enterococcus spp). The Enterobacteriaceae family and non-fermentative bacilli were characterized by glucose oxidation and fermentation $(\mathrm{O} / \mathrm{F})$, oxidase, mobility, arginine hydrolysis, methyl red, indol production, lysine-deaminase, citrate, urea hydrolyses, production of $\mathrm{H}_{2} \mathrm{~S}$ and pigmentation, as pyoverdin and pyocyanin synthesis. EPM Mili and NF II (Probac, Brasil, BR) kits were used to presumptive identification of fermentative and non-fermentative bacteria, respectively. Gram strain, morphology, catalase production, presence and position of endospores identified the aerobic gram-positive bacilli. Mycobacterium spp contamination in centrifugates of samples collected from bronchoscopes was searched by bacilloscopy (BAAR). Fungi were initially characterized by their macroscopic and microscopic morphology. The biochemical profile of Candida spp was accessed through sugar assimilation and carbohydrate fermentation. $C$. albicans identification was performed by formation of germ tubes in plasma after $3 \mathrm{~h}$ at $37^{\circ} \mathrm{C}$ and chlamydospore production in Cornmeal agar at room temperature for 48 to 72 hours.

\section{RESULTS}

The manual disinfection of EGDs and colonoscopes at two Brazilian hospitals did not follow a suitable standard system (Table 1). Contamination of $10^{3}-10^{6} \mathrm{cfu} / \mathrm{mL}$ was verified in samples recovered from endoscopes after patient examination. Colonoscopes, usually, presented microbial levels above $10^{5} \mathrm{cfu} / \mathrm{mL}$. Samples of endoscopes after using in patients yielded gram-negative bacilli $(\mathrm{n}=142: 56 \%)$, gram-positive cocci $(\mathrm{n}=43: 17 \%)$, yeast cells $(\mathrm{n}=43: 17 \%)$, and gram-positive bacilli $(\mathrm{n}=26: 10 \%)$. Approximately $48.32 \%$ ( 72 out of 149 samples) of the samples collected from the endoscopes after undergoing the cleaning and disinfection procedures had a microbial growth over $10^{3} \mathrm{cfu} / \mathrm{mL}$. EGDs were the most frequently contaminated devices (Table 2). Gram-negative bacilli $(\mathrm{n}=55: 61 \%)$, gram-positive cocci $(\mathrm{n}=21$ : $23 \%)$, gram-positive bacilli $(n=8: 9 \%)$ and yeast cells $(n=6: 7 \%)$ were found in decontaminated endoscopes. Pseudomonas aeruginosa, Klebsiella pneumoniae, Escherichia coli, Enterobacter spp, Serratia marcescens, Proteus mirabilis, Citrobacter freundii, Staphylococcus aureus, Staphylococcus coagulose negative, Micrococcus luteus, Candida albicans, C. tropicalis, C. glabrata, C. guilliermondii, Bacillus spp and Corynebacterium spp were predominantly isolated.

\begin{tabular}{|c|c|c|c|c|}
\hline $\begin{array}{l}\text { Hospital } \\
\text { instruments }\end{array}$ & $\mathrm{n}$ & Cleaning & $\begin{array}{c}\text { Solution } \\
\text { disinfection }\end{array}$ & Time (minutes) \\
\hline \multicolumn{5}{|l|}{ Hospital-1 } \\
\hline Bronchoscope & 10 & e. s. + water & $2 \%$ glutaraldehyde & $15-30$ \\
\hline EGDs & 27 & water & $2 \%$ glutaraldehyde & $2-5$ \\
\hline Colonoscope & 30 & e. s. + water & $2 \%$ glutaraldehyde & $5-15$ \\
\hline \multicolumn{5}{|l|}{ Hospital-2 } \\
\hline Bronchoscope & 10 & e. s. + water + us & $2 \%$ glutaraldehyde & $20-30$ \\
\hline EGDs & 42 & e. s. + water & $2 \%$ glutaraldehyde & $5-10$ \\
\hline Colonoscope & 30 & e. s. + water & $2 \%$ glutaraldehyde & $10-20$ \\
\hline
\end{tabular}

$n=$ total number of collected samples

e.s.. $=$ enzymatic solution
us $=$ ultrasound

TABLE 2 - Microbial results of samples obtained after endoscope processing

\begin{tabular}{lcccc}
\hline $\begin{array}{l}\text { Hospital } \\
\text { instruments }\end{array}$ & $\begin{array}{c}\text { Samples } \\
\mathrm{n}\end{array}$ & \multicolumn{2}{c}{ Contaminated } & \multirow{2}{*}{$\begin{array}{c}\text { Samples X CFU/mL } \\
\text { (TSA) }\end{array}$} \\
\cline { 3 - 4 } & & $\mathrm{n}$ & $\%$ & \\
\hline $\begin{array}{l}\text { Hospital-1 } \\
\quad \text { Bronchoscope }\end{array}$ & 10 & - & - & \\
$\quad$ EGDs & 27 & 13 & 48.14 & $5.1 \times 103$ \\
$\quad$ Colonoscope & 30 & 21 & 70.00 & $3.8 \times 106$ \\
Hospital-2 & & & & \\
$\quad$ Bronchoscope & 10 & - & - & \\
$\quad$ EGDs & 42 & 23 & 54.76 & $2.4 \times 103$ \\
$\quad$ Colonoscope & 30 & 15 & 50.00 & $1.7 \times 104$ \\
Total & 149 & 72 & 48.32 & \\
\hline
\end{tabular}

EGDs = esophagogastroduodenoscopes

$n=$ total number of samples
$C F U=$ colony forming units

TSA = tryptic soy agar

\section{DISCUSSION}

Hospital infections acquired by contaminated endoscopes are rare if suitable cleaning and high-level disinfection procedures are performed. Microbial resistance to biocides and establishment of biofilms are other important factors related with decontamination failure ${ }^{(22,30)}$. Thus, the potential risk of nosocomial transmission of infections associated with the use of unsuitably decontaminated endoscopes should be always considered. 
Currently, Brazilian manual or mechanical decontamination has involved enzymatic detergent cleaning and $2 \%$ glutaraldehyde disinfection. The National Health of Surveillance Agency (ANVISA) recommends disinfection time of 30 minutes with $2 \%$ glutaraldehyde ${ }^{(4)}$. However, we detected variations in the disinfection time, which is not conform with ANVISA recommendations (see Table 1). Similar problem was also related by $\operatorname{COSTA}^{(10)}$, in 1996. In our study, short time of disinfection were found to be the major issues associated with the presence of microorganisms in EGDs. The positiveness of colonoscope samples should be related to inefficient cleaning process.

Contamination of medical devices can be due to environmental sources, patients or hospital staff ${ }^{21,29}$. Random environmental specimens of rinse water collected showed that the main contamination source come from patients. Filtered water and $70 \%$ alcohol usually were used to rinse the endoscopes after disinfection.

Endoscopes contamination by mycobacteria, gram-negative bacilli and fungi is a well-recognized problem ${ }^{(11,19,24,28)}$. MERIGHI et al. ${ }^{(23)}$ recovered most frequently Pseudomonas spp, Ps. aeruginosa and Staphylococcus spp from both external and internal parts of EGDs and colonoscopes. An important cause of after-endoscopy infections was related to $P$ s. aeruginos $a^{(2,3)}$. ALVARADO et al. ${ }^{(3)}$ reported an association of $P$. aeruginos $a$ with sepses in individuals submitted to endoscopic examinations. In our investigation, P. aeruginosa was the most frequently microorganism isolated from endoscope samples and patients were the main source. Their predominance in processed endoscopes disclosed the inherent ability of this microorganism to resist enzymes and detergents with cationic and alkaline proprieties, besides their ability to form biofilm ${ }^{(8,14,18)}$. The high frequency of $K$. pneumoniae, E. coli and $S$. marcescens was also raised in EGDs and colonoscopes. Sometimes, polymicrobial contamination by such agents was seen. After decontamination procedure yeast cells have been more commonly isolated than moulds ${ }^{(17,20,27)}$. The transmission of uncommon yeast cells after unsuitably processed endoscope has been related to two cases of esophagitis by T. asahii in immunocompromized patients ${ }^{(20)}$. In this research, Candida species were cultured from EGDs unsuitably disinfected.

Some viruses may be present in both secretions and excretions (e.g.: sputum, gastric juice, saliva and enteric mucous) aspirated by endoscopes. HIV is easily eliminated of endoscopes by disinfection routine ${ }^{(15,16)}$. However, errors in endoscope cleaning and disinfection increase the risk of HBV transmission ${ }^{(9,12)}$. BÉCHEUR et al ${ }^{(6)}$ pointed out that instruments internal channel, where aspirated secretions go through, were the main site involved in $\mathrm{HCV}$ risk of cross-infection. RNA viral of HCV was reported in endoscopes decontaminated (29\%) with $2 \%$ glutaraldehyde, suggesting that the transmission was possible after reprocessing ${ }^{(25)}$. Helicobacter pylori DNA was detected in $61 \%$ of endoscope samples from patients infected by this microorganism ${ }^{(13)}$. But, after disinfection for 20-30 minutes, the bacterial DNA was not amplified. By analyzing the identified germs, disinfection was considered of intermediate to low-level, especially for EGDs (Figure 1). In addition to the potential risk of transmission of the isolated species, other infectious agents such as Helicobacter pylori, Mycobacterium tuberculosis, hepatitis B and $\mathrm{C}$ viruses, which were not detected by classical identification methods could also be transmitted through endoscopes.

Failures in chemical decontamination procedures may occur in health centers of less developed countries where manual disinfection prevails. So, it is important that these results should be spread in

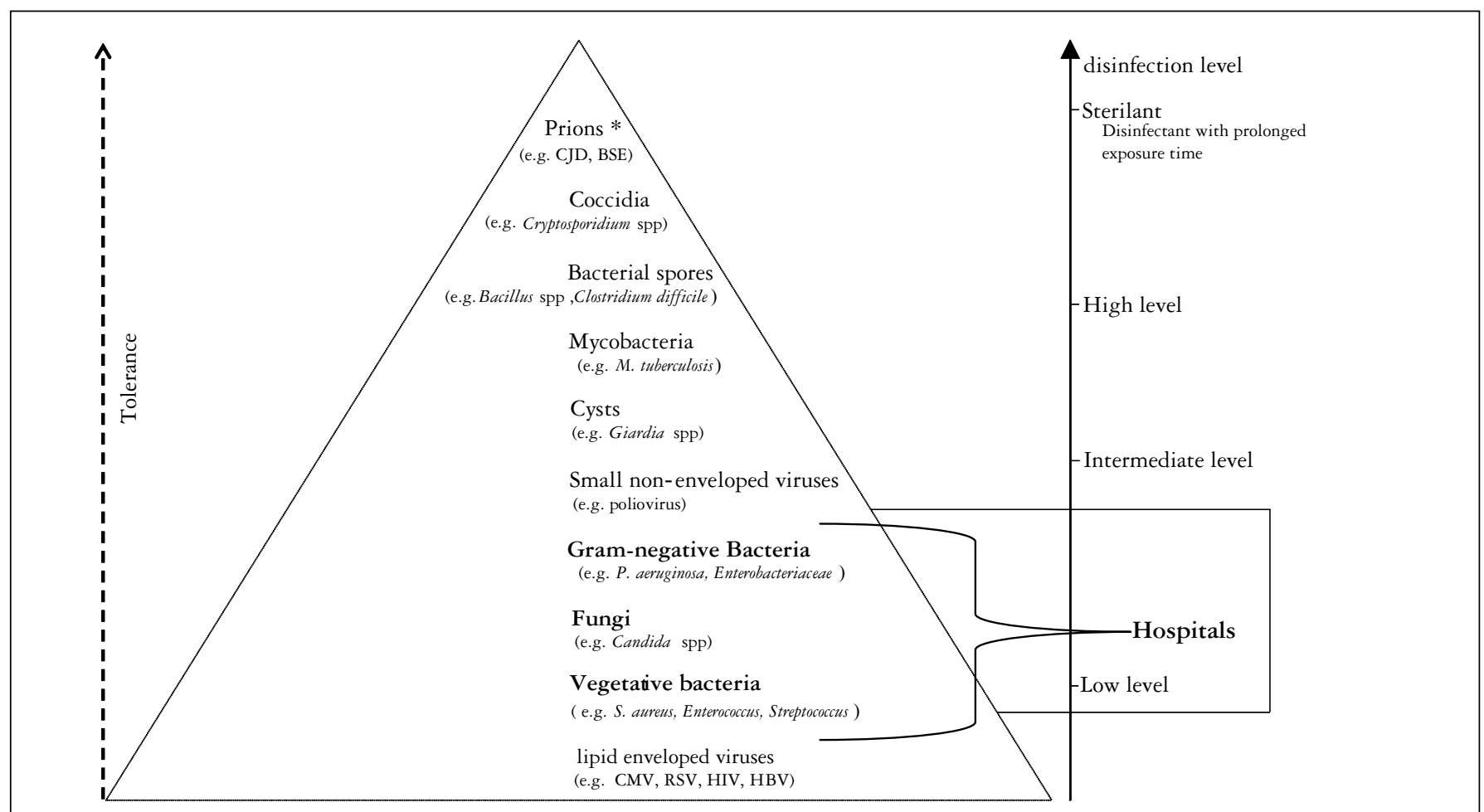

FIGURE 1 - Increase order of microbial tolerance to disinfectant chemicals and correlation with microorganisms recovered from processed endoscopes at two Brazilian hospitals. "The asterisk indicates that the conclusions are not yet universally agree upon. (Adapted from McDONNELL and RUSSELL ${ }^{(22)}$; WIDMER and FREI ${ }^{(30)}$ 
these countries, to call attention towards the importance of careful manual disinfection as well as the periodical bacteriological culture for monitoring disinfected endoscopes. The intense gastroscopy routine and the lack of familiarity with the correct use and action of biocides by health care professionals might have been the main causes of unsuitable cleaning and disinfection procedures. Technicians and endoscope users revealed interest on reviewing protocols after the investigation. Later on, significant changes occurred specially at the EGDs and colonoscope decontamination routine procedures followed within two Brazilian hospitals, in terms of increasing disinfection time and improving both facilities and staff conditions of endoscope cleaning and disinfection.

\section{ACKNOWLEDGMENTS}

To National Council of Science and Technology (CNPq) by the fellowship, and to medical and nursing staff of the studied hospitals by their cooperation with this investigation.

Machado AP, Pimenta ATM, Gontijo PP, Geocze S, Fischman O. Estudo microbiológico da desinfecção de endoscópios flexíveis em dois hospitais brasileiros. Arq Gastroenterol. 2006;43(4):255-8.

RESUMO - Racional - Endoscópios são rotineiramente utilizados em hospitais e clínicas e podem ser fontes potenciais de infecção cruzada quando a descontaminação é inadequada. Objetivo - As rotinas de descontaminação dos endoscópios flexíveis (broncoscópios, gastrocópios e colonoscópios) realizadas em dois hospitais universitários do Brasil foram avaliadas durante 3 anos. Material e métodos - Amostras aleatórias foram coletadas dos canais internos dos endoscópios, depois que o aparelho era utilizado nos pacientes e após o processo de desinfecção. Resultados - Contaminação superior a 103 foi verificada em amostras coletadas após o exame endoscópico, sendo isolado bacilos gram-negativos $(n=142: 56 \%)$, cocos gram-positivos $(n=43: 17 \%)$, leveduras $(n=43: 17 \%)$ e bacilos grampositivos $(\mathrm{n}=26: 10 \%)$. Em 72 das 149 amostras coletadas após procedimentos de limpeza e desinfecção, detectou-se bacilos gram-negativos $(\mathrm{n}=55: 61 \%)$, cocos gram-positivos $(\mathrm{n}=21: 23 \%)$, bacilos gram-positivos $(\mathrm{n}=8: 9 \%)$ e leveduras $(\mathrm{n}=6: 7 \%)$. Gastroscópios e colonoscópios eram os aparelhos com maior freqüência e taxa de contaminação. Pseudomonas aeruginosa, Klebsiella pneumoniae, Escherichia coli, Enterobacter spp, Serratia marcescens, Proteus mirabilis, Citrobacter freundii, Staphylococcus aureus, Staphylococcus coagulase negative, Micrococcus luteus, Candida albicans, C. tropicalis, C. glabrata, C. guilliermondii, Bacillus spp and Corynebacterium spp foram os mais identificados. Conclusão - A limpeza inapropriada e curto período de tempo de desinfecção eram, respectivamente, os maiores fatores associados com a presença de microrganismos em gastroscópios e colonoscópios. De acordo com os organismos isolados, considera-se que a desinfecção nos hospitais era de nível baixo a intermediário. Após a investigação, os centros de endoscopia adequaram seus protocolos, sanando os problemas verificados nos procedimentos de descontaminação dos endoscópios.

DESCRITORES - Contaminação de equipamentos. Desinfecção. Endoscópios.

\section{REFERENCES}

1. Ahuja V,Tandon RK. Survey of gastrointestinal endoscope disinfection and accessory reprocessing practices in the Asia-Pacific region. J Gastroenterol Hepatol. 2000;15 Suppl:G78-81.

2. Allen JI, Allen MO, Olson MM, Gerding DN, Shanholtzer CJ, Meier PB, Venne JA, Silvis SE. Pseudomonas infection of the biliary system resulting from use of a contaminated endoscope. Gastroenterology. 1987;92:759-63.

3. Alvarado CJ, Stolz SM, Maki DG. Nosocomial infections from contaminated endoscopes: a flawed automated endoscope washer. An investigation using molecular epidemiology. Am J Med. 1991;91(3B):272s-80s.

4. Anvisa (2005)- Item 381 - www.anvisa.gov.br//faqdinamica/

5. Axon AT, Beilenhoff U, Bramble MG, Ghosh S, Kruse A, McDonnell GE, Neumann C, Rey JF, Spencer K, Guidelines Committee. European Society of Gastrointestinal Endoscopy (ESGE). Variant Creutzfeldt-Jakob disease (vCJD) and gastrointestinal endoscopy. Endoscopy. 2001;33:1070-80.

6. Bécheur H, Harzic, Colardelle P, Deny P, Coste T, Dubeaux B, Chochon M, RoussinBretagne S, Doll J, Andrieu J. Hepatitis C virus contamination of endoscopes and biopsy forceps. Gastroenterol Clin Biol. 2000; 24:906-10.

7. Belleguic C, Léna H, Desrues B, Delaval P. Prévention des infections transmises par les endoscopes bronchiques. Rev Pneumol Clin. 2001;57:67-72.

8. Campanac C, Pineau L, Payard A, Baziard-Mouysset G, Roques C. Interactions between biocide cationic agents and bacterial biofilms. Antimicrob Agents Chemother. 2002;46:1469-74

9. Chiaramonte M, Farini R, Truscia D, Zampieri L, Di Mario F, Pornaro E, Vecchiati U, Naccarato R. Risk of hepatitis B virus infection following upper gastrointestinal endoscopy: a prospective study in an endemic area. Hepatogastroenterology. 1983;30:189-91.

10. Costa MLM. Evaluation of esophagogastroduodenoscope reprocessing in hospitas of Sao Paulo (Brazil) [Dissertation in Portuguese]. Sao Paulo: Federal University of Sao Paulo; 1996.

11. Culver DA, Gordon SM, Mehta AC. Infection control in the bronchoscopy suite: a review of outbreaks and guidelines for prevention. Am J Respir Crit Care Med. 2003;167:1050-6.

12. Deva AK, Vickery K, Zou J, West RH, Selby W, Benn RA, Harris JP, Cossart YE. Detection of persistent vegetative bacteria and amplified viral nucleic acid from in-use testing of gastrointestinal endoscopes. J Hosp Infect. 1998;39:149-57.

13. Fantry GT, Zheng QX, James SP. Conventional cleaning and disinfection techniques eliminate the risk of endoscopic transmission of Helicobacter pylori. Am J Gastroenterol. 1995;90:227-32.

14. Grobe KJ, Zahller J, Stewart PS. Role of dose concentration in biocide efficacy against Pseudomonas aeruginosa biofilms. J Ind Microbiol Biotechnol. 2002;29:10-5.

15. Hanson PJ, Gor D, Jeffries DJ, Collins JV. Elimination of high titre HIV from fibreoptic endoscopes. Gut. 1990;31:657-9.
16. Hanson PJ, Jeffries DJ, Collins JV. Viral transmission and fibreoptic endoscopy. J Hosp Infect. 1991;18 Suppl A:136-40.

17. Hoffmann KK, Weber DJ, Rutala WA. Pseudoepidemic of Rhodotorula rubra in patients undergoing fiberoptic bronchoscopy. Infect Control Hosp Epidemiol. 1989;10:511-4.

18. Jones MV, Herd TM, Christie HJ. Resistance of Pseudomonas aeruginosa to amphoteric and quaternary ammonium biocides. Microbios. 1989;58:49-61.

19. Leung JW. Reprocessing of flexible endoscopes. J Gastroenterol Hepatol. 2000;15 Suppl:G73-7.

20. Lo Passo C, Pernice I, Celeste A, Perdichizzi G, Todaro-Luck F. Transmission of Trichosporon asahii oesophagitis by a contaminated endoscope. Mycoses. 2001;44:13-21.

21. Martin MA. Nosocomial Infections related to patient care support services: dietetic services, central services department, laundry, respiratory care, dialysis, and endoscopy. In: Wenzel RP, editor. Prevention and control of nosocomial infections. $2^{\text {nd }}$ ed. Baltimore: Wiliams \& Wilkins; c1993. p.93-138.

22. McDonnell G, Russell AD. Antiseptics and disinfectants: activity, action, and resistance. Clin Microbiol Rev. 1999;12:147-79. Review. Erratum in: Clin Microbiol Ver. 2001;14(1):227.

23. Merighi A, Contato E, Scagliarini R, Mirolo G, Tampieri ML, Pazzi P, Gullini S. Quality improvement in gastrointestinal endoscopy: microbiologic surveillance of disinfection. Gastrointest Endosc. 1996;43:457-62.

24. Nelson DB. Infectious disease complications of GI endoscopy: part II, exogenous infections. Gastrointest Endosc. 2003;57:695-711.

25. Sakai N, Tatsuta M, Iishi H, Yano H, Osaka S, Aoki A. Effectiveness of manual cleaning and disinfection of gastroendoscopes with $3 \%$ glutaraldehyde for decreasing risk of transmission of hepatitis C virus. Am J Gastroenterol. 2001;96:1803-6.

26. Sattar SA, Tetro J, Springthorpe VS, Giulivi A. Preventing the spread of hepatitis B and C viruses: where are germicides relevant? Am J Infect Control. 2001;29:187-97.

27. Singh S, Singh N, Kochhar R, Mehta SK, Talwar P. Contamination of an endoscope due to Trichosporon beigelli. J Hosp Infect. 1989;14:49-53.

28. Tandon RK. Disinfection of gastrointestinal endoscopes and accessories. J Gastroenterol Hepatol. 2000;15 Suppl:G69-72.

29. Weber D, Rutala WA. Environmental isses and nosocomial infections. In: Wenzel RP, editor. Prevention and control of nosocomial infections. $2^{\text {nd }}$ ed. Baltimore: Wiliams \& Wilkins; c1993. p.420-49.

30. Widmer AF, Frei R. Decontamination, disinfection, and sterilization. In: Murray PR, Baron EJ, Pfaller MA, editors. Manual of clinical microbiology. $7^{\text {th }}$ edition. Washington: American Society for Microbiology; c1999. p.138-62.

Recebido em 18/7/2005. Aprovado em 8/6/2006. 